\title{
Contributions to the Draw Resistance of a Burning Cigarette*
}

\author{
by R. R. Baker \\ Group Research and Development Centre, British-American Tobacco Co. Ltd., \\ Southampton, England
}

\section{INTRODUCTION}

One of the factors that determines the yield of smoke from a burning cigarette is its draw resistance. It is well known that the draw resistance of a cigarette increases by about 50 to $60 \%$ when the cigarette is lit $(1-4)$. However, when the cigarette is extinguished, its draw resistance falls to a value similar to that of the unburnt cigarette. The increased draw resistance of the burning cigarette is thus associated with the combustion processes occurring in the coal, rather than an inherent increase in the impedance of the coal. This study is intended to assess how far the present state of knowledge can account for the draw resistance of the burning coal.

\section{Theoretical Background}

The pressure drop across a porous body surrounded by a non-porous envelope, that 'is necessary to maintain a given flow of gas through the body, is given by Darcy's Law+:

$$
\mathrm{V}=\frac{\mathrm{I}}{\mathrm{e}} \mathrm{A} \frac{\mathrm{P}}{\mathrm{L}}
$$

where

$V$ is the flow of gas through the porous body $\left(\mathrm{cm}^{3} \mathrm{~s}^{-1}\right)$, $A$ is the area of cross-section of the body $\left(\mathrm{cm}^{2}\right)$,

$P$ is the pressure drop across the body ( $\mathrm{cm}$ water $\left.{ }^{++}\right)$,

$L$ is the length of the body $(\mathrm{cm})$, and

$\varepsilon$ is the coefficient of impedance of the body ( $\mathrm{cm}$ water $\mathrm{s} \mathrm{cm}^{-2}$ ).

Darcy's Law applies to Newtonian (viscous) flow of the gas. When a cigarette used in the present study is enclosed in an impervious glass tube, a plot of volumetric gas flow against pressure drop is linear (correlation coefficient $=0.997$ for flows in the range

\footnotetext{
+ Equation 1 strictly only applies to $2 n$ incompressible fuid. For gases, the flow rate $V$ depends on the pressure at which it is measured, and Darcy's Law for a gas is often written:

$$
\mathrm{V} \overline{\mathrm{P}}=\mathrm{KAP} / \mathrm{L}
$$

where $\overrightarrow{\mathrm{P}}$ is the mean pressure inside the porous material, and the permeability constant $K\left(-\overline{\mathrm{P}} / \mathbf{2}, \mathrm{cm}^{x} \mathrm{~s}^{-1}\right)$ is pressure dependent. However, in studies on cigaretres, the maximum value of $P$ is so small compared to atmospheric pressure $(<1.3 \%)$ that the effect on $\mathrm{V}$ can safely be neglected, and equation 1 used.

$+1 \mathrm{~cm}$ water $=98 \mathrm{~N} \mathrm{~m}^{-2}$.

" Received for publication: 9th April, 1975. $\left.1-18 \mathrm{~cm}^{3} \mathrm{~s}^{-1}\right)$, indicating that Darcy's Law is applicable.

In the case of a tobacco rod surrounded by a porous paper wrapper, the pressure drop across the rod is smaller than that given by equation 1 , due to leakage of air through the paper. It can be shown $(2,5,6)$, by analogy to the well-documented case of an imperfectly insulated cable (7), and assuming that the radial resistance to air flow into the cigarette is due to the paper, that the pressure drop is given by:

$P=\frac{\varepsilon V}{\pi r^{2}}-\left\{L_{0}+\frac{\tanh \left(L-L_{0}\right) \sqrt{2 c \varepsilon / r}}{\sqrt{2 c \varepsilon / r}}\right\}$

where

$r$ is the radius of the tobacco rod (cm),

$L_{v}$ is the length of rod in an impervious holder $(\mathrm{cm})$,

$\mathrm{L}$ is the total length of the rod $(\mathrm{cm})$, and

$c$ is the paper porosity $\left(\mathrm{cm} \mathrm{s}^{-1}(\mathrm{~cm} \mathrm{water})^{-1}\right)^{* *}$.

Furthermore, if it is assumed that:

(a) the impedance of the coal is entirely located there, and is constant during the smoking process,

and

(b) the paper porosity and tobacco rod impedance are constant along the cigarette length, and during the smoking process,

then equations can be derived relating the pressure drop across the coal to the pressure drop across the whole cigarette and various physical parameters of the unlit cigarette $(1,2$ and 6$)$. Although these equations predict the behaviour of a cigarette with an impervious coal $(2,4)$, the theoretical treatment that led to their derivation gives no indication of the factors that contribute to the draw resistance of the coal. However, Jarman ( $x$ ) has shown that the draw resistance of a tobacco rod increases with the temperature of the gas flowing through it. Furthermore, Lorenzen (4) has shown that the draw resistance of the burning cigarette is related to the viscosity of the hot gases flowing down the tobacco rod.

\footnotetext{
4* Paper porosity $(Z)$ is often quoted in units of $\mathrm{cm}^{3} \min ^{-1}\left(10 \mathrm{~cm}^{2}\right)^{-1}$ $(10 \mathrm{~cm} \text { water) })^{-1}$. Thus the relationship between $Z$ and $c$ is:

$$
c=\frac{z}{6 \cdot 10^{2}} \text {. }
$$




\section{EXPERIMENTAL DETAILS}

The non-filter cigarettes contained a typical Englishtype Virginia blend tobacco, and were $69 \mathrm{~mm}$ long and $8 \mathrm{~mm}$ in diameter. They were wrapped in paper of porosity $0.031 \mathrm{~cm} \mathrm{~s}^{-1}(\mathrm{~cm} \text { water })^{-1}$. The cigarettes were weight $(1.00 \pm 0.01 \mathrm{~g})$ and pressure drop $(3 \%$ variation) selected, and conditioned at $21^{\circ} \mathrm{C}$ and $60 \%$ relative humidity.

The pressure drop across the cigarette during smoking was measured using an Ether type UPI pressure transducer, connected via a $T$ junction between the cigarette and Cambridge filter pad. The output from the transducer was monitored on a Leeds and Northrup Speedomax two-channel recorder during continuous draw smoking, and on a Honeywell type 2500 ultra-violet galvanometer recorder under puffing conditions. The transducer was calibrated against a water manometer.

\section{RESULTS}

\section{A. Cigarette Smoked at a Constant Draw}

1. Pressure Drop Variation as Cigarette is Smoked: The variation in the pressure drop across a lit cigarette, as the cigarette is smoked at a continuous draw of $2.0 \mathrm{~cm}^{3} \mathrm{~s}^{-1}$, is shown in Figure 1. In this experiment, $10 \mathrm{~mm}$ of the cigarette was held in an impervious cigarette holder. Each experimental point is the mean of five determinations, and the deviation of the mean at the $95 \%$ confidence level is indicated by bars. When the cigarette is lit, its total pressure drop rapidly increases as the burning coal is formed, and the pressure drop attains a maximum value, $53 \%$ higher than that of the unlit cigarette, when $7.0 \mathrm{~mm}$ of the

Figure 1. Varlation in pressure drop of the burning cigarette, as the cigarette is smoked at a constant draw of $2.0 \mathrm{~cm}^{3} s-1$. $X$ : Experimental values, with $95 \%$ confidence limits. $\odot$ : Values calculated from the hot-gas model, with maximum estimated error limits. $10 \mathrm{~mm}$ of the cigarette was held in an Impervious holder.

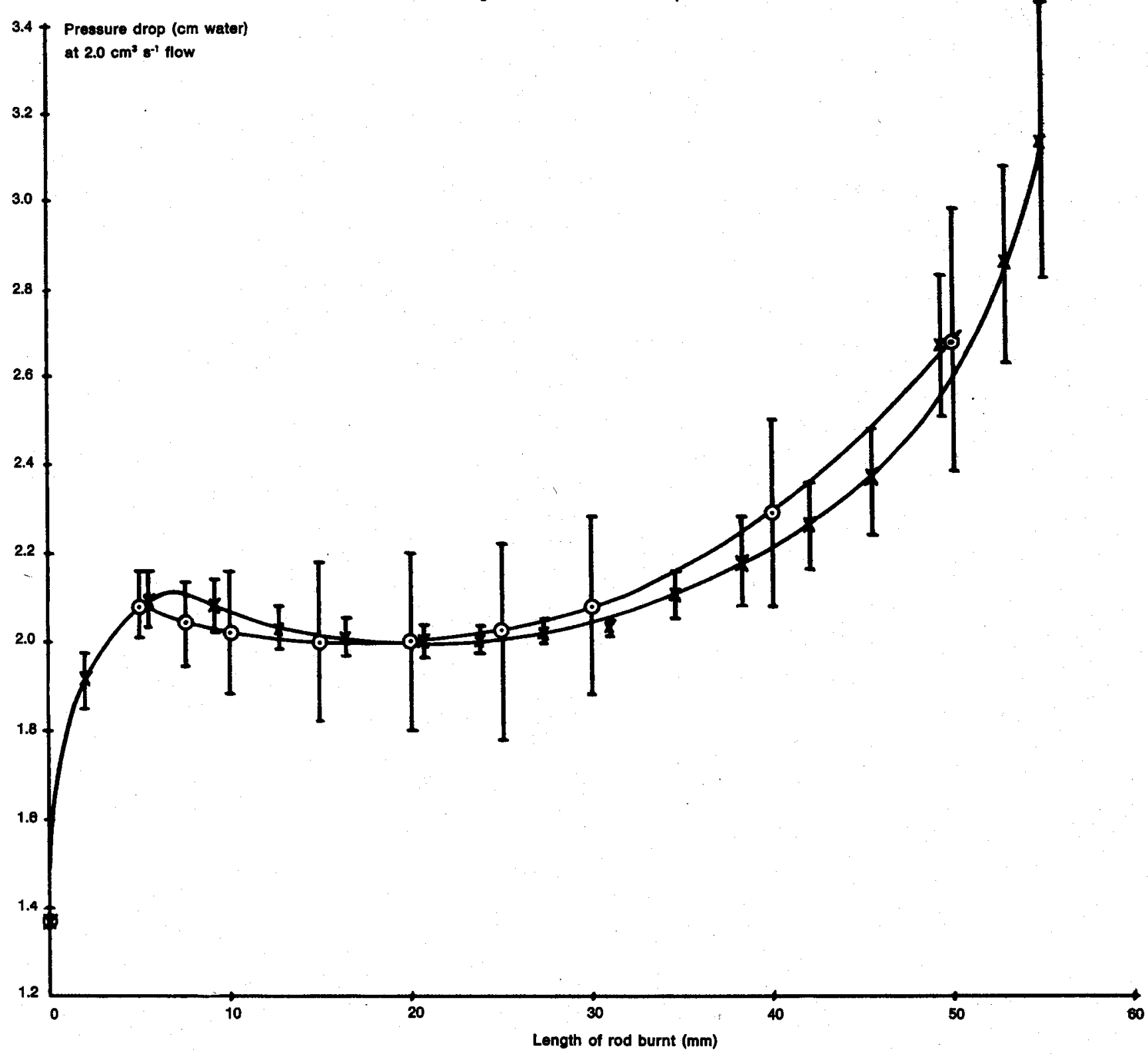


tobacco rod is burnt*. As the cigarette is further smoked, its pressure drop decreases slightly, and it finally continuously increases as the latter $70 \%$ of the tobacco rod is consumed. The deviation of the mean experimental values is about $4-5 \%$ as the coal is being formed and stabilized, and this falls to $1-2 \%$ when the coal is stable at burn lengths of $20-30 \mathrm{~mm}$. As the latter half of the tobacco rod is consumed and the pressure drop across the cigarette increases, the deviation of the mean experimental value increases to a value greater than $10 \%$. This is caused by the somewhat unstable burning of the cigarette as the coal burns through a tobacco rod which has a distinctly wet appearance, caused by the accumulation of condensing material under the continuous draw smoking conditions.

2. Variation of Tobacco Rod Impedance: In another series of experiments, the cigarette was extinguished (by plunging it into nitrogen) after various lengths of the tobacco rod had been consumed. The coal was then cut off the tobacco rod at the line of paper burn, and the pressure drop across the remaining unburnt rod

\footnotetext{
* In this paper, the length of rod is measured to a point at the centre of the line of paper burn, the line of paper burn being a black charred area of about $1 \mathrm{~mm}$ in thickness.
}

Figure 2. Variation of the pressure drop of the unburnt tobacco rod (coal removed) with the length of burn of the rod.

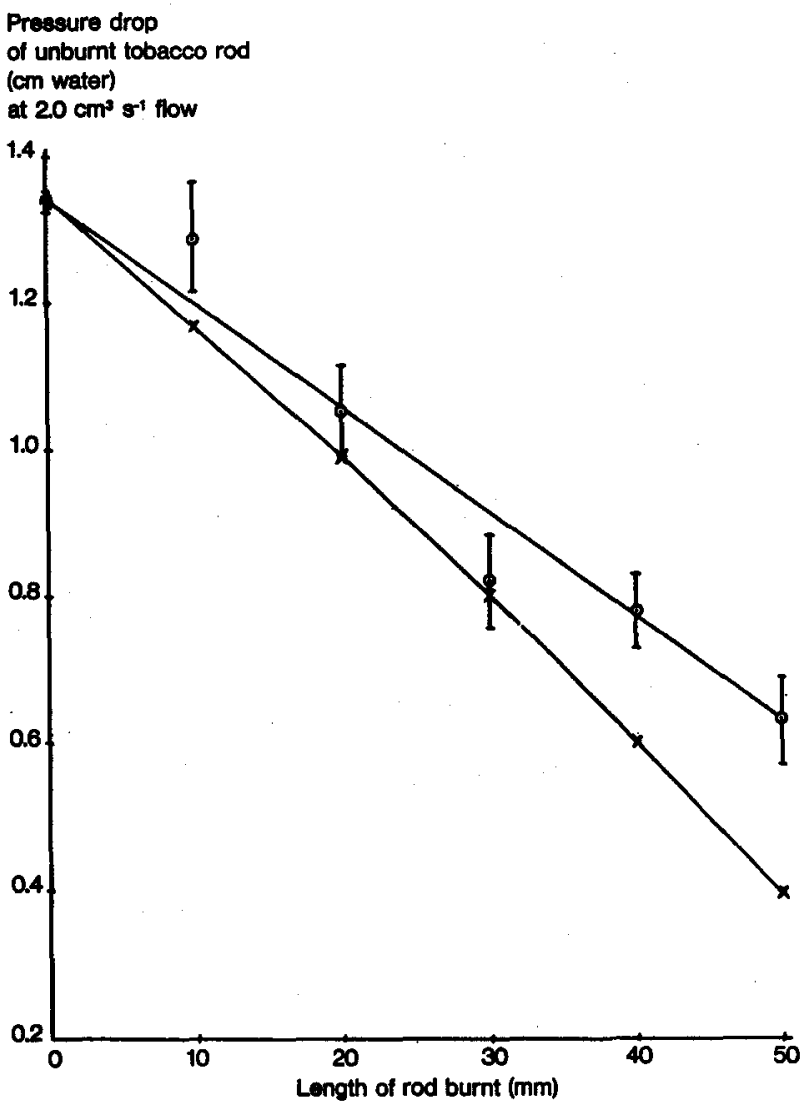

$\odot$ : Pressure drop of unburnt rod, after extinguishing cigarette and removing the coal.

$X$ : Calculated pressure drop of unburnt rod.

$10 \mathrm{~mm}$ of the tobacco rod was held in an Impervious holder. determined. The results (Figure 2) show that the pressure drop across the unburnt rod is larger than that calculated across an equivalent length of the original, unsmoked cigarette (using equation 3 ). The difference is caused by the deposition of smoke onto the rod, which increases its impedance and hence increases the pressure drop across it. The impedance of the unburnt sections of the rod has been obtained by measuring the pressure drops of the rods when enclosed in a glass tube (so that there was no leakage of air through the cigarette paper) in conjunction with equation 1 . Figure 3 shows that the impedance of the unburnt tobacco rod increases sharply as the latter half of the cigarette is consumed.

3. Variation in Pressure Drop as Cigarette is Extinguished: The cigarette was smoked in an enclosed box ( $1840 \mathrm{~cm}^{3}$ internal volume), into which air flowed $\left(180 \mathrm{~cm}^{3} \mathrm{~s}^{-1}\right)$ via a solenoid valve. When $7.5 \mathrm{~mm}$ of the rod had been consumed, the solenoid valve was switched so that the air supply stopped and nitrogen flowed into the box. The air inside the box was almost completely replaced by nitrogen ten seconds after operating the solenoid valves, and the pressure inside the box was always atmospheric. As the cigarette extinguished, the pressure drop across it was monitored, and its variation is shown in Figure 4 (each

Figure 3. Varlation of the impedance of the unburnt tobacco rod behind the coal, as the clgarette is smoked at a constant draw of $2.0 \mathrm{~cm}^{3} \mathrm{~s}^{-1}$.

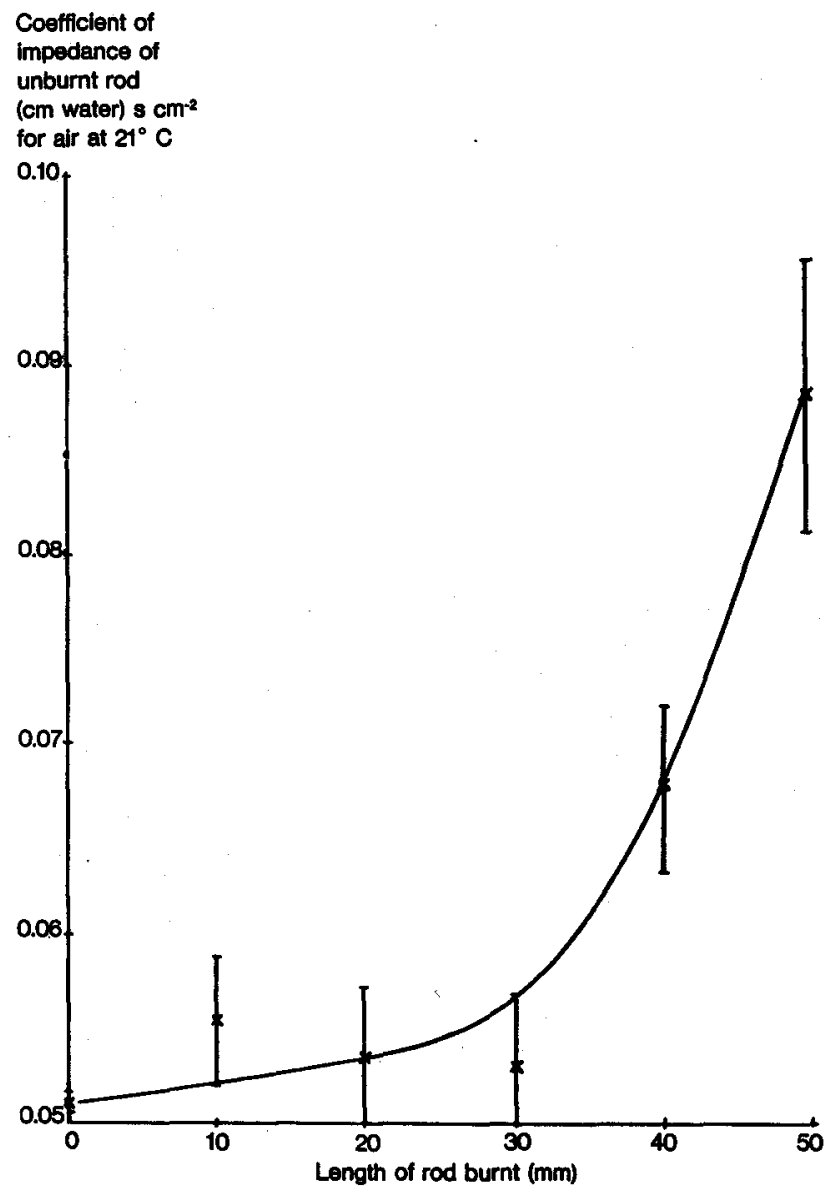


Figure 4. Fall in pressure drop as clgarette is extingulshed by flooding with nitrogen (flow through cigarette $\left.=2.0 \mathrm{~cm}^{2} \mathrm{~s}^{-1}\right)$.

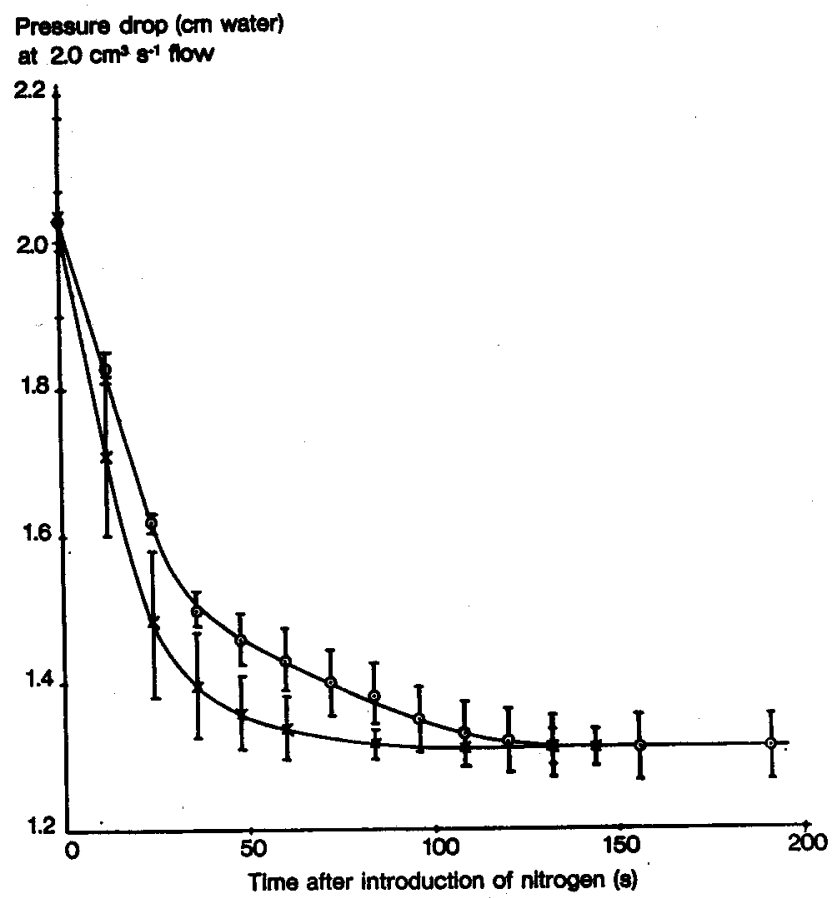

○: Experimental values, with $95 \%$ confidence limits. $X$ : Values calculated from the hot-gas model.

Flgure 5. Varlation In pressure drop during the third puff of the smoking cycle.

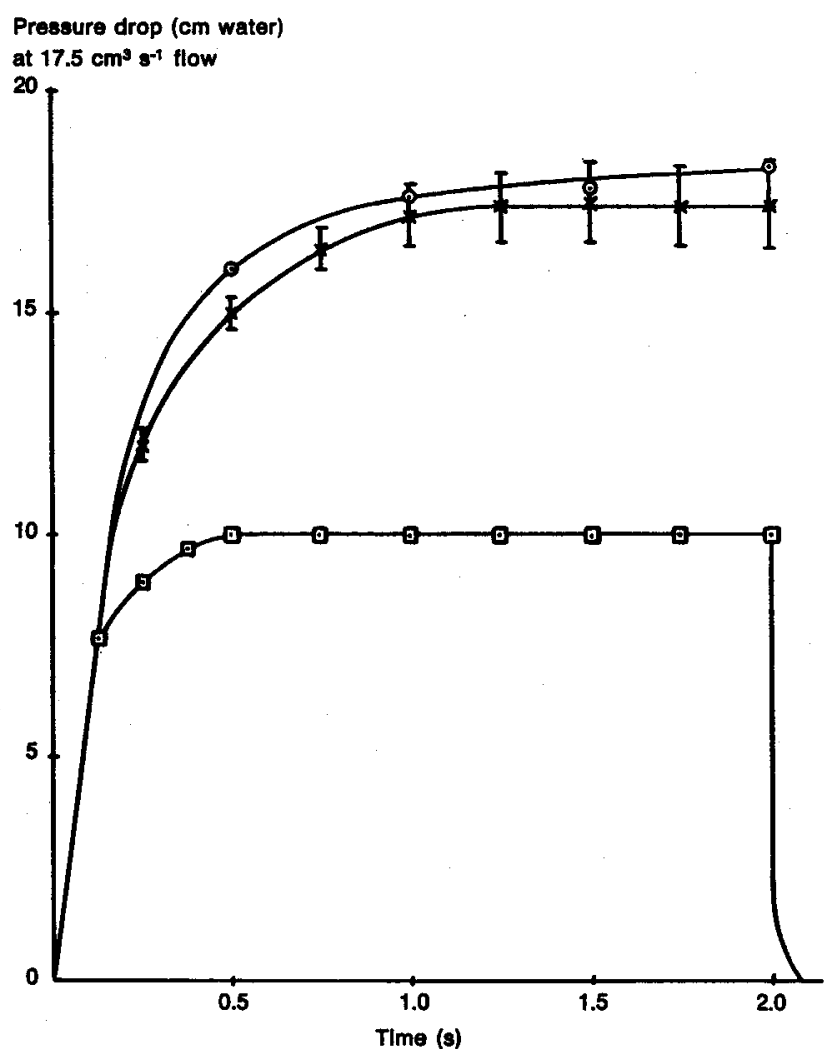

$X$ : Experimental values for the lit cigarette, with $95 \%$ confidence IImits.

$\odot$ : Values calculated from the hot-gas model (maximum estimated error limit is $\pm 1 \mathrm{~cm}$ water).

-]: Experimental values for the unlit clgarette.

$10 \mathrm{~mm}$ of the cigarette was held in an impervious holder. point being the mean of five determinations). The pressure drop across the cigarette gradually fell from a value of $2.03 \pm 0.04 \mathrm{~cm}$ water (at a flow of $2.0 \mathrm{~cm}^{3} \mathrm{~s}^{-1}$ ) for the cigarette burning in air, to $1.31 \pm 0.05 \mathrm{~cm}$ water, for the completely extinguished cigarette.

\section{B. Cigarette Smoked Under Puffing Conditions}

1. Pressure Drop Variation During the Third Puff: In any individual puff, the pressure drop across the burning cigarette increases to a constant value as the puff progresses. This is illustrated in Figure 5 for the third puff of the smoking cycle, with the tobacco rod smoked on a Cigarette Components Ltd. C.S.M. 10 smoking machine, taking a $35 \mathrm{~cm}^{3}$ puff of 2 seconds duration every minute, under restricted smoulder conditions. Each experimental point in Figure 5 is the mean of twenty three determinations.

With an unlit cigarette (also shown in Figure 5), the pressure drop across the cigarette reaches a constant value of $10 \mathrm{~cm}$ water, 0.45 seconds after the start of the puff. During the third puff of the lit cigarette, a constant pressure drop $(17.4 \mathrm{~cm}$ water) is reached 1.2 seconds after the start of the puff.

2. Variation of Tobacco Rod Impedance: The cigarette was extinguished (by plunging it into nitrogen) under the following conditions:

(a) just prior to the third puff being taken,

(b) just after the third puff, and

(c) just prior to the fourth puff.

The impedance of, and weight of condensate deposited on, the unburnt tobacco rod behind the coal, and on sections of the rod, were determined. (The rod was cut into 4 sections with a razor blade, and the impedance and weight of each section was determined.) The results in Table 1 show that, within the limits of experimental variation, the impedance of any section of the rod, and the whole rod behind the coal, is virtually independent of:

(1) the time in the puff/smoulder cycle, in the region of the third puff. (The impedance of the complete unburnt rod is very slightly larger just after the third puff.)

(2) the distance of the section of the rod from the coal.

The majority of the condensate was deposited on the section of the rod (7.1-11.5 mm long) just behind the coal. A weight decrease was always found in the $14 \mathrm{~mm}$ section of the rod nearest the mouth end of the cigarette, presumably due to the evaporation of water and other volatiles from the tobacco rod.

\section{CALCULATIONS}

The coefficient of impedance $(\varepsilon)$ of a body is directly proportional to the coefficient of viscosity ( $\eta$, poise, i.e. $\mathrm{g} \mathrm{cm}^{-1} \mathrm{~s}^{-1}$ ) of the fluid flowing through the body (8). 
Table 1. Varlation of coefficlent of Impedance $(\xi)$ and amount of condensate deposited, with distance behind coal.

\begin{tabular}{|c|c|c|c|c|c|c|c|c|c|c|c|}
\hline \multirow{2}{*}{$\begin{array}{l}\text { Position in } \\
\text { smoking cycle }\end{array}$} & \multicolumn{5}{|c|}{$\varepsilon\left([\mathrm{cm}\right.$ water $\left.] \mathrm{s} \mathrm{cm}^{-2}\right)$} & \multicolumn{5}{|c|}{$\begin{array}{l}\text { Weight of condensate per } \mathrm{cm} \\
\text { of unburnt rod }(\mathrm{mg} \mathrm{cm}-1)\end{array}$} & \multirow{2}{*}{$\begin{array}{l}\text { Length of } \\
\text { section } 1 \\
\text { (mm) }\end{array}$} \\
\hline & $\begin{array}{l}\text { Unburnt } \\
\text { rod }\end{array}$ & Section 1* & Section $2^{*}$ & Section $3^{*}$ & Section 4* & $\begin{array}{c}\text { Unburnt } \\
\text { rod }\end{array}$ & Section $1^{*}$ & Section $2^{*}$ & Section $3^{\star}$ & Section 4" & \\
\hline $\begin{array}{l}2 \text { puffs }+58 \text { s } \\
\text { smoulder }\end{array}$ & 0.0427 & 0.044 & 0.042 & 0.042 & 0.039 & 1.1 & 3.2 & $-0.3++$ & 0.8 & $-3.6++$ & 11.5 \\
\hline 3 puffs & 0.0446 & 0.047 & 0.043 & 0.043 & 0.040 & 1.7 & 7.7 & 1.6 & $-0.1++$ & $-3.4++$ & 10.1 \\
\hline $\begin{array}{l}3 \text { puffs }+58 \mathrm{~s} \\
\text { smoulder }\end{array}$ & 0.0428 & 0.044 & 0.042 & 0.043 & 0.040 & 0.7 & 5.2 & $-0.2++$ & 2.1 & $-4.2++$ & 7.1 \\
\hline $\begin{array}{l}\text { Standard error } \\
( \pm) \text { at } 95 \% \\
\text { confidence level + }\end{array}$ & $\begin{array}{r}0.0006 \\
+\end{array}$ & 0.003 & 0.003 & 0.002 & 0.003 & 0.3 & 0.3 & 0.3 & 0.3 & 0.3 & 0.3 \\
\hline
\end{tabular}

Original (unsmoked) plain cigarette:

$\begin{array}{ll}\text { length } & =69 \mathrm{~mm} \\ \text { weight } & =1.00 \pm 0.01 \mathrm{~g}\end{array}$

pressure drop $=10.0 \pm 0.1 \mathrm{~cm}$ water at $17.5 \mathrm{~cm}^{3} \mathrm{~s}^{-1}$ flow of air

$\equiv$ a coefflcient of impedance for the tobacco rod of $0.0427 \pm 0.0004$ (cm water) $\mathrm{s} \mathrm{cm-2}$

- Sectlons 2, 3 and 4 of the unburnt tobacco rod were $14 \mathrm{~mm}$ long. Section 1 (nearest the coal) was of variable length.

\begin{tabular}{|l|l|l|l|l|}
\hline Coal & 1 & 2 & 3 & 4 \\
\hline
\end{tabular}

+ Each of the above results is the mean of ten determinations. $10 \mathrm{~mm}$ of the cigarette was heid in an impervious holder during the experiments.

++ Negative welghts signify that the weight of this sectlon of the rod is less than in the original (unburnt) cigarette - 1 . e. that some constituents have been lost from the tobacco.

Thus, according to equation 3 the pressure drop across a given length of tobacco rod is dependent on the flow rate of gas through the rod (V) and $\varepsilon$ (and hence $\eta$ ), both of which vary with the temperature of the flowing fluid. In the following calculation, the total pressure drop across a burning cigarette is obtained by summing the pressure drops across individual sections of the cigarette, each section containing flowing gas at different temperatures.

\section{The Hot-Gas Model}

Consider a tobacco rod of total length $\mathrm{L} \mathrm{cm}$, of which $L_{0} \mathrm{~cm}$ is enclosed in an impervious holder (Figure 6). The contribution to the total pressure drop across the rod, of a section of rod of length $\delta x$ with boundaries $x=x_{n}$ and $x=x_{n-1}$, is given by:

$$
P\left(x_{n}-x_{n-1}\right)=P\left(x_{n}-0\right)-P\left(x_{n-1}-0\right)
$$

Figure 6. Calculation of pressure drop.

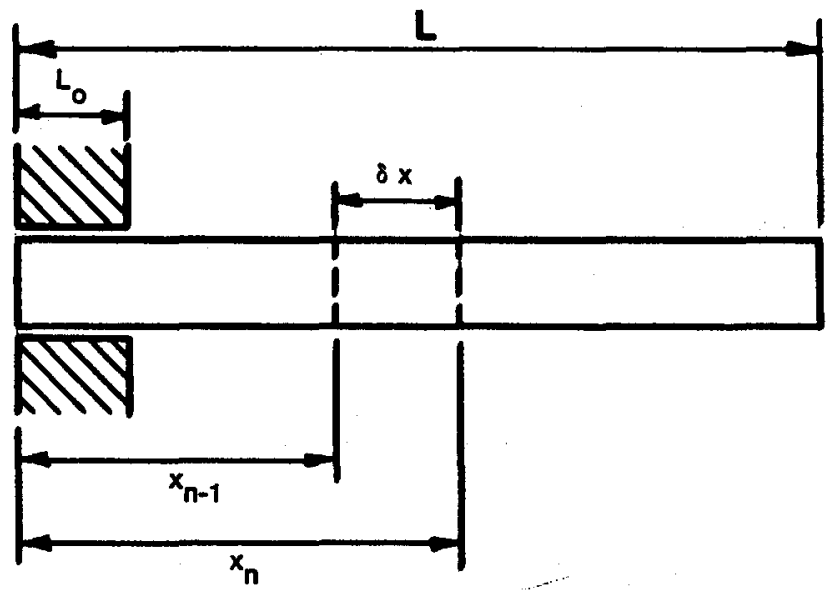

where

$P\left(x_{n}-x_{n-1}\right)$ is the pressure drop across the section of the rod of length $\delta x$,

and

$P\left(x_{n}-0\right)$ is the pressure drop across the section of the rod of length $x_{n}$ (i.e. from $x=o$ to $x=x_{n}$ ).

When $\mathrm{x}_{\mathrm{n}}>\mathrm{L}_{\mathrm{u}}$

$P\left(x_{n}-0\right)=\frac{\varepsilon V}{\pi r^{2}}\left\{L_{0}+\frac{\tanh \left(x_{n}-L_{0}\right) \sqrt{2 c \varepsilon / r}}{\sqrt{2 c \varepsilon / r}}\right\}$.

When $x_{n}<L_{0}$,

$$
P\left(x_{n}-0\right)=\frac{\varepsilon V x_{n}}{\pi r^{2}}
$$

The total pressure drop across the whole rod is given by:

$$
P=\sum_{x_{n-1}=0}^{x_{n}=L} P\left(x_{n}-x_{n-1}\right) .
$$

In equations 6 and $7, \varepsilon$ is the coefficient of impedance of the rod as measured by flowing air at room temperature, and $V$ is the flow rate out of the mouth end of the rod (at $x=0$ ), measured at room temperature. If the flowing gas in the section of the rod of length $\delta x$ is $T\left({ }^{\circ} \mathrm{K}\right)$, then the local impedance and gas flow through this section of the rod are respectively $\varepsilon \eta_{T} / \eta_{0}$ and $V_{T}$, where $\eta T$ and $\eta_{0}$ are the gas viscosities at $T$ and room temperature, and $V_{T}$ is the local flow rate at temperature $T$. Since the 
overall pressure inside the rod is near atmospheric, the gases will be ideal and so $V_{T}=V_{0} T / T_{0}$, where $V_{0}$ is the flow rate of the gas at room temperature and $T_{0}$ is room temperature. Consequently, the pressure drop across the section of the rod of length $\delta x$ and at temperature $T\left(P_{T}\right)$ is given by:

$$
\mathrm{P}_{\mathrm{T}}=\frac{\eta_{\mathrm{T}} \mathrm{T} \mathrm{P}_{0}}{\eta_{\mathrm{0}} \mathrm{T}_{\mathrm{0}}}
$$

where $P_{0}$ is the pressure drop across the section at room temperature, given by equation 5 .

Thus, using the known gas-phase temperature distributions in the tobacco rod and coal as the cigarette is smoked (9-11) and extinguished, and the known variation of the impedance of the tobacco rod as the cigarette is smoked (Figure 3 and Table 1 ), the pressure drop across a burning cigarette can be calculated using equations 5-9, if the following assumptions are made:

1. The coefficient of impedance of the unburnt rod (Figure 3 for continuous draw conditions, and Table 1 for puffing) is constant along the unburnt rod at room temperature, and is equal to the impedance of the coal at room temperature, at a given extent of consumption.

2. The ash in front of the coal does not contribute to the pressure drop across the burning cigarette.

3. The variation with temperature of the viscosity of the gases flowing down the tobacco rod is identical to the variation with temperature of the viscosity of air.

4. In a given section of the rod, $\delta x \mathrm{~cm}$ long and of the same radius as the rod, the mean gas temperatures in that section can be used to calculate the mean gas viscosity and flow rate in that section.
Assumption number three is not critical, since the major gas-phase components in the smoke (nitrogen, water, carbon monoxide, carbon dioxide, and oxygen) all have viscosities whose variation with temperature closely parallels that of air (12).

Examination of the position of the ash in rapidly extinguished cigarettes, in conjunction with the known gas-temperature distributions in the coal of the burning cigarette $(9-11)$, indicates that the ash is completely formed at a distance of less than about $2 \mathrm{~mm}$ in front of the maximum mean gas temperature across a radius in the coal when the cigarette is smoked under continuous draw conditions. During the third puff of a puff/ smoulder smoking regime, the ash is completely formed less than $2 \mathrm{~mm}$ in front of the maximum axial gas temperature. Thus, from the point of view of pressure drop calculations, sections of the rod and coal are included in the summation up to, and including, $1 \mathrm{~mm}$ beyond the mean maximum radial temperature (continuous draw) or maximum axial gas temperature (puffing) in the coal. These distances extend up to $7-8 \mathrm{~mm}$ in front of the line of paper burn under both puffing and continuous draw conditions, once a stable coal is formed.

\section{Calculation of Pressure Drop During Smoking}

An example of the calculation of the pressure drop across the burning cigarette is given in Table 2. From the table, it is seen that $79 \%$ of the increase in pressure drop when a cigarette is lit, is due to combustion processes in the coal which occur in front of the line of paper burn. The rest of the combustion pressure drop is due to hot gases in the unburnt tobacco rod, behind the paper burn line.

Table 2. Calculation of pressure drop across burning tobacco rod, when smoked at a continuous draw of $2.0 \mathrm{~cm}^{3} \mathrm{~s}-1$ and $20 \mathrm{~mm}$ of the rod is consumed*.

\begin{tabular}{|c|c|c|c|c|c|c|}
\hline \multirow{2}{*}{$\begin{array}{l}\text { Section } \\
(\mathrm{mm})^{\star \star \star}\end{array}$} & \multirow{2}{*}{\multicolumn{2}{|c|}{$\begin{array}{l}\text { Mean gas-temperature } \\
\text { in section }\left({ }^{\circ} \mathrm{C}\right)\end{array}$}} & \multicolumn{2}{|c|}{$P$ (cm water) } & \multirow{2}{*}{$\frac{\left(P_{T}-P_{0}\right) 100 \% 0^{+}}{\Sigma\left(P_{T}-P_{0}\right)}$} & \multirow{2}{*}{$\begin{array}{c}\text { Total calculated } \\
\text { error in } \mathrm{P}_{\mathrm{T}} \\
( \pm \mathrm{cm} \text { water) }\end{array}$} \\
\hline & & & $\underset{\text { (unlit) }}{\mathbf{P}_{0}}$ & $\begin{array}{l}P_{T} \\
\text { (lit) }\end{array}$ & & \\
\hline $0-26$ & 22 & \multirow{4}{*}{$\begin{array}{l}\text { Unburnt tobacco rod } \\
\text { behind the line of } \\
\text { paper burn }\end{array}$} & 0.567 & 0.567 & 0 & 0.040 \\
\hline $26-36$ & 50 & & 0.211 & 0.246 & 4.3 & 0.031 \\
\hline $36-46$ & 75 & & 0.202 & 0.268 & 8.0 & 0.035 \\
\hline $46-49$ & 195 & & 0.0585 & 0.129 & 8.6 & 0.019 \\
\hline $49-50$ & 382 & \multirow{7}{*}{$\begin{array}{l}\text { Coal in front of the line } \\
\text { of paper burn }\end{array}$} & 0.0193 & 0.0675 & 5.9 & 0.011 \\
\hline $50-51$ & 500 & & 0.0192 & 0.0979 & 9.6 & 0.015 \\
\hline $51-52$ & 583 & & 0.0190 & 0.114 & 11.6 & 0.017 \\
\hline $52-53$ & 616 & & 0.0189 & 0.125 & 12.9 & 0.018 \\
\hline $53-54$ & 633 & & 0.0188 & 0.125 & 12.9 & 0.018 \\
\hline $54-55$ & 642 & & 0.0185 & 0.126 & 13.2 & 0.018 \\
\hline $55-56$ & 640 & & 0.0183 & 0.123 & 12.8 & 0.018 \\
\hline \multicolumn{3}{|c|}{ Total for all the sections: } & 1.17 & 1.99 & 100 & 0.24 \\
\hline
\end{tabular}

- Coefficient of impedance of unburnt tobacco rod $=0.053$ (cm water) $\mathrm{s} \mathrm{cm}^{-2}$.

Paper porosity $=0.031 \mathrm{~cm} \mathrm{~s}^{-1}$ (cm water) $)^{-1}$.

$10 \mathrm{~mm}$ of tobacco rod held in Impervlous cigarette holder.

- Distances of the boundarles of the section from the mouth end of the cigarette.

+ This is the contribution ( $\%)$ of this section to the total pressure drop of the burning cigarette due to combustion processes. 
An estimate of the total calculated error in the pressure drop of each section of the burning cigarette is also given in Table 2. This is an accumulation of the errors in the measured parameters used to calculate the pressure drop, namely errors in the coefficient of impedance, ${ }^{*}$ paper porosity ${ }^{* *}$, and temperature distribution. The latter error also produces an uncertainty in the viscosity of the gases. The total error in the calculated pressure drop of the burning cigarette is $\pm 12 \%$.

The calculated pressure drops are shown in Figures 1 , 4 and 5.

\section{CONCLUSIONS}

Within the limits of experimental error, and errors in the calculations, the hot-gas model can predict the observed variation in pressure drop across a burning cigarette, under the following conditions:

(x) when the cigarette is smoked under continuous draw conditions, up to a burn length of $50 \mathrm{~mm}$ (Figure 1),

(2) as the cigarette is extinguished in nitrogen, and its pressure drop falls (Figure 4 ),

and

\section{(3) as the 2-second puff progresses (Figure 5).}

Consequently, it is concluded that the increased pressure drop of a lit cigarette, and its variations as the cigarette is smoked, is due entirely to the variation with temperature of the total flow rate and viscosity of the gases inside the cigarette, together with variation of the impedance of the unburnt rod.

The direction of flow of gases through the coal is not in an axial direction - the major gas-flow into the coal during a puff is initially in a radial direction, just in front of the line of paper burn (11). The flow direction becomes axial behind the coal. However, since the hotgas model uses mean temperatures in given sections of the coal and rod, the exact direction of the flow in that section does not appear to be critical to the model. Since the model only uses sections of the coal up to $8 \mathrm{~mm}$ in front of the line of paper burn, the gases in the coal further from the paper burn line can be considered as static, and as making no contribution to the total flow, within experimental error.

\section{SUMMARY}

The draw resistance of a cigarette increases by about $50-60 \%$ when the cigarette is lit, and the total draw

\footnotetext{
* From equation 6 it can be shown that 2 given percentage errot in the coefficient of impedance ( $t$ ) produces an almost idestical percentage error in the pressure drop.

* The accuracy of the quoted paper porosity is $\pm 5 \%$. This introduces an error into the calculated pressure drop $P$ (equation 6) which is dependent on the length of tobacco rod used in the equation. However, even with the maximum length of rod in the quation $(6.9 \mathrm{~cm})$, the resulting error in $P$ is less than $0.4 \%$.
}

resistance of the burning cigarette varies in a distinct manner as it is smoked. This effect is not normally due to an inherent increase in the impedance of the coal, because the effect disappears when the cigarette is extinguished. Rather, the effect is due to the heating of the gases flowing through the coal and down the tobacco rod, in particular

(a) the increase in gas viscosity with temperature,

(b) the increase in volumetric gas flow due to thermal expansion,

and

(c) the increase in the impedance of the unburnt tobacco rod, due to the deposition of smoke condensate on the rod.

A hot-gas model, using the above contributing factors together with the known gas-phase temperature distribution inside the burning cigarette, can predict quantitatively (within the limits of experimental error) the observed variations of the draw resistance of a burning cigarette.

\section{ZUSAMMENFASSUNG}

Der Zugwiderstand einer Cigarette nimmt um etwa 50 bis $60 \% z u$, wenn die Cigarette angezündet wird, und der Gesamtzugwiderstand der brennenden Cigarette variiert während des Verrauchens in einer bestimmten Art. Diese Wirkung ist normalerweise nidht auf eine inhärente Erhöhung des Widerstandes der Glutzone zurïckzuführen, denn sie verschwindet, wenn die Cigarette gelöscht wird. Sie beruht vielmehr auf der Erhitzung der Gase, die Glutzone und Tabakstrang durchströmen, insbesondere auf

(a) Zunahme der Viskosität der Gase mit der Temperatur,

(b) Anwachsen des Volumenflusses der Gase durch Wärmeausdehnung,

(c) Erhöhung des Widerstandes des nicht verbrannten Teiles des Tabakstranges durch die dortige Kondensatablagerung.

Aufgrund eines Heiß-Gas-Modells, das die beteiligten Faktoren zusammen mit der bekannten GasphasenTemperaturverteilung in der brennenden Cigarette benutzt, können die beobaditeten Veränderungen des Zugwiderstandes einer brennenden Cigarette (innerhalb der experimentellen Fehlergrenzen) quantitativ vorausgesagt werden.

\section{RESUME}

La résistance au tirage d'une cigarette augmente d'environ 50 à $60 \%$ quand elle est allumée, et la résistance totale au tirage d'une cigarette bralante varie d'une façon distincte quand elle est fumée. Cet effet n'est 
normalement pas imputable a une augmentation inhérentè de l'impédance du cône, puisque l'effet disparaît quand on éteint la cigarette. Cet effet est plutôt dû à l'échauffement des gaz passant par le cône et le long du boudin de tabac, en particulier:

(a) l'augmentation de la viscosité du gaz avec la température,

(b) l'augmentation du fux volumétrique de gaz due à l'expansion thermique, et

(c) l'accroissement de l'impédance du boudin de tabac non brâlé, dû au dépôt de condensat de fumée.

Un modèle de gaz chaud, tenant compte des facteurs ci-dessus et de la distribution connue de la température dans la phase gazeuse dans la cigarette brollante, permet de prédire de façon quantitative (dans les limites d'erreur expérimentale) les variations observées dans la résistance au tirage d'une cigarette bralante.

\section{REFERENCES}

1. Jarman, R. T.: Paper presented at the Fourteenth Tobacco Chemists' Research Conference, WinstonSalem, N. C., U.S.A., October 1960.

2. Meyer-Abich, K. M.: Beitr. Tabakforsch. 3 (Ig66) 307.
3. Lorenz, H.W., and F. Seehofer: Beitr. Tabakforsch. $6(x 97 x) x$.

4. Lorenzen, H. C.: Paper presented at the Fourteenth Quester Tobacco Colloquium,. Amsterdam, June 1972.

5. Fordyce, W. B., I. W. Hughes, and M. G. Ivinson: Tobacco Sci. 5 : (1961) 70.

6. Somasundaran, P, and K. J. Mysels: Paper presented at the Coresta/Tobacco Chemists' Joint Conference, Williamsburg, Va., U.S.A., October 1972.

7. Slater, J. C.: Microwave transmission; McGrawHill, London and New York, 1942, Chapter 1.

8. Grove; D. M.: Permeability and flow studies; Chapter 4 of: Porous carbon solids, edited by R. L. Bond, Academic Press, London, 1967.

9. Baker, R. R., and K. D. Kilburn: Beitr. Tabakforsch. 7 (1973) 79.

to. Baker, R. R.: Nature 247 (1974) 405.

11. Baker, R. R.: High Temperature Science, in press.

12. Handbook of chemistry and physics; The Chemical Rubber Company, Cleveland, Ohio, 51 st edition, 1970-71.

\section{The author's address:}

Group Research and Development Centre, British-American Tobacco Co. Ltd., Regent's Park Road, Southampton, $S \mathrm{O}_{9} 1 \mathrm{PE}$, England. 